\title{
Co-ensiling garlic stalk with citrus pulp improves the fermentation quality and feed-nutritional value
}

\author{
Youn Hee Lee', Farhad Ahmadi', Young II Kim', Young-Kyoon Oh², and Wan Sup Kwak ${ }^{1, *}$
}

* Corresponding Author: Wan Sup Kwak Tel: +82-43-840-3521, Fax: +82-43-851-8675,

E-mail: wsk@kku.ac.kr

${ }^{1}$ Division of Food Bio-science, College of Medical Life Sciences, Konkuk University, Chungju 27478, Korea

${ }^{2}$ Animal Nutrition and Physiology Team, National Institute of Animal Science, Rural Development Administration, Wanju 55365, Korea

\section{ORCID}

Youn Hee Lee

https://orcid.org/0000-0001-6238-3762 Farhad Ahmadi

https://orcid.org/0000-0002-8760-053X Young II Kim

https://orcid.org/0000-0003-3888-9530

Young-Kyoon Oh

https://orcid.org/0000-0002-5817-1748

Wan Sup Kwak

https://orcid.org/0000-0002-7829-8172

Submitted Jun 7, 2019; Revised Aug 1, 2019; Accepted Aug 14, 2019
Objective: Ensiling is a simple and effective method for long-term preservation; however, less information exists about the ensilability characteristics of garlic stalk (GS). Therefore, the objectives were to examine the ensiling feasibility of GS.

Methods: The GS was ensiled alone or inoculated with Lactobacillus plantarum KU5 in the presence or absence of $5 \%$ molasses and ensiled for 7, 14, and $28 \mathrm{~d}$. As an alternative storage method, GS was co-ensiled with wet citrus pulp (CP) at different proportions (GS:CP: 70:30, 60:40, 50:50, and 40:60). Analysis was made on physicochemical, fermentative, and nutritional parameters.

Results: The GS was found to be a biomass which is difficult to ensile. A combination of microbial inoculant and molasses was successful in the improvement of the silage fermentation quality of GS. Co-ensiling of GS with wet CP at the mixing ratio of 50:50 provided the most desirable silage fermentation parameters, including the substantial lactic acid formation, low final $\mathrm{pH}$, minor effluent loss, and the more favorable organoleptic properties.

Conclusion: Co-ensiling GS with CP appears to be a simple and viable method of conservation, enabling the more efficient utilization of these by-product resources over a prolonged period.

Keywords: Garlic Stalk; Citrus Pulp; Ensiling; Lactic Acid Bacteria; Molasses; Feed

\section{INTRODUCTION}

The worldwide production of garlic amounted to 27 million tons in 2016, with China, India, and Korea being the major garlic producing countries [1]. Nearly $70 \%$ of the total garlic product is discarded as stalk, which could be used as a potential roughage source in a ruminant diet [2,3]. However, during the harvesting season large quantities of garlic stalk (GS) accumulate, which exceeds the amount needed for immediate use. Thus, the surplus is simply decomposed into the soil or incinerated, the latter resulting in environmental concerns $[2,4]$. This demands the development of an efficient conservation technology for its long-term use.

The ensiling process is an effective and simple conservation technology that is known to acidify biomass, thus it inhibits the growth of spoilage-causing microorganisms, thereby providing safe and long-term conservation for moist forages [5]. Inoculation with lactic acid bacteria (LAB) or supplementation with readily fermentable carbohydrates (readily metabolizable by LAB), such as molasses, proved to be successful in enhancing the efficiency of the ensiling process. This supplies an additional source of simple sugars for the growth and multiplication of LAB, thereby accelerating the silage acidification and avoiding microbial deterioration, especially when the ensiling biomass has a low concentration of soluble carbohydrates [5,6]. More recently, the simultaneous application of the LAB inoculant and 
molasses successfully improved the silage fermentation quality of various crops $[7,8]$.

Citrus is one of the major fruits in Korea, which is mainly cultivated on Jeju Island and the southern coast line of the main land, with an estimated production of 0.68 million tons in 2011 [9]. An estimated 30\% of citrus fruits is directed into the processing industries, resulting in the generation of about $50 \%$ to $60 \%$ organic waste [10]. Citrus pulp (CP), the main byproduct of citrus processing facilities, is rich in the fermentable carbohydrates but high in moisture content (approximately $80 \%$ to $90 \%$ ), which is associated with difficulties in its transportation, handling, and perishability $[11,12]$. Moreover, the high moisture content of CP results in effluent loss during ensiling, which is associated with the loss of silage nutrients and environmental worries arising from the pollution of surface and ground water [13]. Additionally, the high residual sugars give $\mathrm{CP}$ a wet and sticky nature that raises issues associated with its conservation in silos [12]. Earlier studies mainly investigated the dried CP as animal feed; however, drying is an expensive process and therefore an improper method for large-scale recycling of CP [12]. However, the appropriate mixing of $\mathrm{CP}$ with dry ingredients, to maintain the proper moisture content for silage making, would contribute to the efficient recycling of high-moisture CP [11]. Therefore, we hypothesized that combining GS (as a drier by-product) and $\mathrm{CP}$ could enhance the silage fermentation quality of the two by-products.

To our knowledge, limited reports are available concerning the silage fermentation characteristics of GS. Therefore, the first objective was to evaluate how Lactobacillus plantarum (L. plantarum) inoculation without or with molasses would affect the silage fermentation patterns of GS. The second objective was to develop an alternative storage method through co-ensiling of GS with CP at different proportions, and determine the appropriate mixing ratio for efficient silage fermentation.

\section{MATERIALS AND METHODS}

\section{Collection of garlic stalk and inoculum preparation}

Different batches of sun-dried GS were provided from a garlic processing plant located in Uysung County, KyungBuk province and an agricultural marketing center located in Chungju city, Chung-Buk province in Korea. Before silage making, GS was cut into pieces of 20 to $30 \mathrm{~mm}$ and handmixed thoroughly, then divided into the respective treatments. L. plantarum KU5 (Accession No. HQ542227) inoculant was re-cultivated for 3 consecutive days on MRS (de Mann Rogosa Sharpe) broth (Difco Laboratories Inc., Detroit, MI, USA) at $36^{\circ} \mathrm{C}$ for $24 \mathrm{~h}$, before being applied onto the biomass.

\section{Silage making}

The GS was ensiled in nylon-polyethylene pouches ( 5 replicates per each treatment) without inoculant or with $L$. plantarum KU5 (LAB) in the absence or presence of $\%$ molasses (LAB+ $\mathrm{M})$. Ensiling duration was 7, 14, and $28 \mathrm{~d}$ at room temperature $\left(20^{\circ} \mathrm{C}\right.$ to $\left.24^{\circ} \mathrm{C}\right)$. The detailed description of the silage making procedure is reported in our previous article [8]. The suspension containing the LAB inoculant was applied onto the mixture using a manual sprayer at a rate to provide $1 \times 10^{6} \mathrm{cfu} / \mathrm{g}$ of fresh mass. In a subsequent experiment, GS was mixed with $\mathrm{CP}$ at decremental proportions of 70:30, 60:40, 50:50, and 40:60 (wet weight), mixed manually, and then assigned to respective treatments. The packing density of approximately $200 \mathrm{~kg}$ dry matter $(\mathrm{DM}) / \mathrm{m}^{3}$ was applied for all silages, before the sealing of the polyethylene silos. From the designated silo openings, the representative samples were collected randomly for the subsequent analyses.

\section{Chemical and microbiological analyses}

Contents of DM, crude protein ( $\mathrm{N} \times 6.25)$, ether extract, crude ash, neutral-detergent fiber (NDF), and acid detergent fiber, both corrected for residual ash, were determined according to the standard methods of the Association of Official Analytical Chemists [14]. True protein was determined after precipitation in $5 \%$ trichloroacetic acid solution [15]. Nonprotein nitrogen was calculated as " 100 - true protein". Nonfibrous carbohydrate (NFC) was computed as 100 - (crude protein $+\mathrm{NDF}+$ ether extract + crude ash). For silage juice extraction, a $20 \mathrm{~g}$ sample of fresh or silage biomass was mixed with deionized autoclaved water $(200 \mathrm{~mL})$ and blended (DIAX 900, Heidolph, Schwabach, Germany) for $1 \mathrm{~min}$. The suspension was filtered through two layers of medical gauze, and was used for the measurement of $\mathrm{pH}$ (HI 9321, Hanna Instruments, Woonsocket, RI, USA), water-soluble carbohydrates (WSC, glucose equivalent) [16], lactic acid [17], and NH3-N [18] using a UV-visible spectrophotometer (S1100, Scinco, Daejeon, Korea). The viable colonies of total bacteria and LAB were counted using the spread-plating method on plate count agar and MRS agar, respectively. Plates were incubated (JSGI-050T, Hanyang Scientific Equipment Co., Ltd., Seoul, Korea) at $36^{\circ} \mathrm{C}$ for $48 \mathrm{~h}$.

\section{Data analysis}

Data analyses were performed using the general linear model procedure (Statistix7, 2000). Treatment effects were evaluated with the analysis of variance in a completely randomized design. Each mini-silo was considered as the experimental unit. Microbial counts were transformed to $\log 10$-scale before statistical analysis. The difference among treatments was identified using Tukey's multiple range test. Values less than 0.05 probability level were considered significant. Tendency was discussed at $0.05<\mathrm{p}<0.1$. 


\section{RESULTS AND DISCUSSION}

\section{Silage fermentation quality of garlic stalk}

The silage fermentation metabolites and chemical composition of GS ensiled for 7, 14, or $28 \mathrm{~d}$, are presented in Table 1 . Initial $\mathrm{pH}$ before ensiling was 8.06 , which declined $(\mathrm{p}<0.01)$ as the length of ensiling prolonged (a 1.26-unit decline by $\mathrm{d}$ 28 of ensiling). Lactic acid concentration was greatest after $28 \mathrm{~d}$ of fermentation. This is associated with the development of LAB which tended to increase $(p=0.07)$ as fermentation duration continued. With ensiling, WSC content decreased while $\mathrm{NH}_{3}-\mathrm{N}$ formation increased considerably (a 4.4-times increase after $28 \mathrm{~d}$ of ensiling), which indicates the microbial conversion of WSC into lactic acid and protein breakdown during ensiling, respectively $[5,19]$. The chemical composition of GS silage differed negligibly as ensiling duration progressed. Crude protein content declined slightly with ensiling $(\mathrm{p}<$ 0.002), which can possibly be explained by the protein breakdown (proteolysis) during ensiling, which releases $\mathrm{NH}_{3}-\mathrm{N}$ [5].

An approximate number of $8 \log _{10}$ cfu of LAB per gram of fresh biomass is the required $\mathrm{LAB}$ number to ensure the fast decline of silage $\mathrm{pH}$ [20]. In the present experiment, although the population of epiphytic LAB was adequate $\left(7.93 \log _{10} \mathrm{cfu} / \mathrm{g}\right)$ to promote fast acidification and efficient ensiling, the silage fermentation was not successful, as evidenced by high $\mathrm{NH}_{3}-\mathrm{N}$ content and high silage $\mathrm{pH}$ after $28 \mathrm{~d}$ of fermentation. This suggests that GS is a difficult-to-ensile biomass. This can be justified by three explanations: i) The GS contains an inadequate content of WSC, which probably did not provide sufficient sugars for lactic acid production, and thus silage mass acidification $[5,6]$. ii) The GS contains a high ash concentration (approximately 15\%), which would increase the buffering capacity, thus resisting silage mass acidification [5]. iii) GS has a hollow and tubular structure [4] that increases the porosity of GS mass, accelerates the aerobic microbial activity during the early phase of ensiling, and thus converts readily available carbohydrates into carbon dioxide and water [5]. These factors collectively result in an inefficient anaerobic fermentation and slow acidification [20]. Based on these assumptions, the follow-up experiment attempted to improve the fermentation quality of GS with LAB inoculation in the presence of molasses as a source of WSC.

The silage fermentation dynamics of GS inoculated with $\mathrm{LAB}$ in the absence or presence of molasses in relation to the length of ensiling ( 7,14 , and $28 \mathrm{~d}$ ), are presented in Table 2. Generally, the fermentation quality parameters of GS silage treated with a combination of $\mathrm{LAB}+\mathrm{M}$ were preferable to those of untreated or LAB-treated silages. After $7 \mathrm{~d}$, silage $\mathrm{pH}$ declined from the initial value of 7.7 in the control silage to 5.8 in the $\mathrm{LAB}+\mathrm{M}$ silage, indicating that the combination of LAB and molasses promoted the favorable silage fermentation pattern.

Inoculation with $\mathrm{LAB}$ prior to ensiling has been successful in the promotion of desirable fermentation patterns. However, when the epiphytic population of $\mathrm{LAB}$ exceeds the inoculant application rate, the domination of inoculant bacteria in the silage is difficult [21]. In the present experiment, the natural population of LAB in GS was close to $8 \log \mathrm{cfu} / \mathrm{g}$ of fresh GS (prior to ensiling), which considerably exceeded the LAB

Table 1. Silage quality parameters and chemical composition of garlic stalk in relation to the ensiling duration

\begin{tabular}{|c|c|c|c|c|c|c|}
\hline \multirow{2}{*}{ Items } & \multicolumn{4}{|c|}{ Ensiling duration (d) } & \multirow{2}{*}{ SE } & \multirow{2}{*}{ p-value } \\
\hline & 0 & 7 & 14 & 28 & & \\
\hline \multicolumn{7}{|l|}{ Silage quality parameters } \\
\hline $\mathrm{pH}$ & $8.06^{c}$ & $7.68^{b}$ & $7.69^{b}$ & $6.80^{\mathrm{a}}$ & 0.28 & $<0.001$ \\
\hline WSC ( $\%$ of DM) & $2.10^{\mathrm{a}}$ & $1.51^{b}$ & $1.92^{\mathrm{a}}$ & $1.44^{b}$ & 0.20 & 0.021 \\
\hline Lactic acid (\% of DM) & $0.42^{\mathrm{a}}$ & $0.40^{\mathrm{a}}$ & $0.42^{\mathrm{a}}$ & $0.49^{b}$ & 0.03 & 0.013 \\
\hline $\mathrm{NH}_{3}-\mathrm{N}(\mathrm{ppm})$ & $143^{\mathrm{a}}$ & $311^{b}$ & $424^{b}$ & $631^{c}$ & 24.8 & $<0.001$ \\
\hline Lactic acid bacteria, $\log _{10}\left(f u / g^{1)}\right.$ & 7.93 & 8.36 & 8.15 & 8.23 & 0.13 & 0.069 \\
\hline \multicolumn{7}{|l|}{ Chemical composition } \\
\hline Dry matter (\%) & 63.2 & 64.4 & 63.5 & 62.8 & 0.81 & 0.325 \\
\hline Crude protein (\% of DM) & $7.02^{\mathrm{a}}$ & $7.01^{\mathrm{a}}$ & $6.40^{b}$ & $6.32^{b}$ & 0.20 & 0.002 \\
\hline True protein (\% of crude protein) & 57.8 & 52.8 & 56.2 & 52.8 & 1.31 & 0.123 \\
\hline NPN (\% of crude protein) & 42.2 & 47.2 & 43.8 & 47.2 & 1.33 & 0.123 \\
\hline NDF ( $\%$ of DM) & 49.7 & 50.4 & 48.8 & 49.4 & 1.41 & 0.532 \\
\hline ADF ( $\%$ of DM) & 48.4 & 49.9 & 50.2 & 48.9 & 1.54 & 0.806 \\
\hline Ether extract ( $\%$ of DM) & 1.73 & 1.58 & 1.57 & 1.70 & 0.21 & 0.974 \\
\hline Crude ash ( $\%$ of DM) & 15.9 & 15.5 & 16.9 & 16.7 & 0.34 & 0.322 \\
\hline
\end{tabular}

Means of five observations.

SE, standard error; WSC, water-soluble carbohydrates; DM, dry matter; NPN, non-protein nitrogen; NDF, neutral detergent fiber; ADF, acid detergent fiber.

1) Colony-forming units per gram of fresh biomass or silage mass.

a-c Means with different superscripts within the same row differ. 
Table 2. Effects of microbial inoculant without or with molasses on the silage quality parameters of garlic stalk after 7, 14, and $28 \mathrm{~d}$ of ensiling

\begin{tabular}{|c|c|c|c|c|c|}
\hline \multirow{2}{*}{ Items } & \multicolumn{3}{|c|}{ Treatment $^{1)}$} & \multirow{2}{*}{ SE } & \multirow{2}{*}{ p-value } \\
\hline & Control & LAB & $\mathrm{LAB}+\mathrm{M}$ & & \\
\hline \multicolumn{6}{|l|}{ Ensiled for $7 \mathrm{~d}$} \\
\hline $\mathrm{pH}$ & $7.7^{\mathrm{a}}$ & $7.5^{\mathrm{a}}$ & $5.8^{b}$ & 0.31 & 0.001 \\
\hline WSC ( $\%$ of DM) & $1.5^{c}$ & $2.0^{b}$ & $2.4^{\mathrm{a}}$ & 0.23 & 0.002 \\
\hline Lactic acid (\% of DM) & 0.40 & 0.42 & 0.44 & 0.02 & 0.298 \\
\hline $\mathrm{NH}_{3}-\mathrm{N}(\mathrm{ppm})$ & 311 & 349 & 284 & 27.9 & 0.116 \\
\hline Lactic acid bacteria, $\log _{10} \mathrm{cfu} / \mathrm{g}^{2)}$ & 8.4 & 8.8 & 8.8 & 0.20 & 0.107 \\
\hline \multicolumn{6}{|l|}{ Ensiled for $14 \mathrm{~d}$} \\
\hline $\mathrm{pH}$ & $7.7^{\mathrm{a}}$ & $7.7^{\mathrm{a}}$ & $5.4^{b}$ & 0.30 & $<0.001$ \\
\hline WSC (\% of DM) & $1.9^{\mathrm{ab}}$ & $1.7^{\mathrm{b}}$ & $2.3^{\mathrm{a}}$ & 0.21 & 0.009 \\
\hline Lactic acid (\% of DM) & $0.42^{b}$ & $0.42^{b}$ & $0.64^{\mathrm{a}}$ & 0.07 & 0.027 \\
\hline $\mathrm{NH}_{3}-\mathrm{N}(\mathrm{ppm})$ & $424^{a b}$ & $502^{\mathrm{a}}$ & $362^{b}$ & 30.9 & 0.006 \\
\hline Lactic acid bacteria, $\log _{10} \mathrm{cfu} / \mathrm{g}$ & $8.2^{b}$ & $8.4^{b}$ & $8.9^{\mathrm{a}}$ & 0.11 & 0.001 \\
\hline \multicolumn{6}{|l|}{ Ensiled for $28 \mathrm{~d}$} \\
\hline $\mathrm{pH}$ & $6.8^{\mathrm{a}}$ & $6.3^{\mathrm{ab}}$ & $5.3^{b}$ & 0.31 & 0.042 \\
\hline WSC ( $\%$ of DM) & 1.4 & 1.4 & 1.7 & 0.10 & 0.050 \\
\hline Lactic acid (\% of DM) & 0.49 & 0.54 & 0.66 & 0.06 & 0.070 \\
\hline $\mathrm{NH}_{3}-\mathrm{N}(\mathrm{ppm})$ & 631 & 553 & 475 & 56.9 & 0.071 \\
\hline Lactic acid bacteria, $\log _{10} \mathrm{cfu} / \mathrm{g}$ & 8.2 & 8.4 & 8.5 & 0.24 & 0.230 \\
\hline
\end{tabular}

Means of five observations.

$\mathrm{SE}$, standard error; DM, dry matter; WSC, water-soluble carbohydrates.

1) Control, no inoculant; LAB, 0.5\% (v/w) Lactobacillus plantarum KU5; LAB+M, 0.5\% (v/w) Lactobacillus plantarum KU5+5\% molasses.

2) Colony-forming units per gram of fresh biomass or silage mass.

${ }^{a-c}$ Means with different superscripts within the same row differ.

application rate $\left(10^{6} \mathrm{cfu} / \mathrm{g}\right.$ of fresh GS). Surprisingly, LAB+M treatment promoted the more favorable fermentative patterns (with respect to a lower $\mathrm{pH}$ and less $\mathrm{NH}_{3}-\mathrm{N}$ production) than untreated or LAB-treated silage. After $28 \mathrm{~d}$ of ensiling, $\mathrm{LAB}+\mathrm{M}$-treated silage showed a $35 \%$ increase in lactic acid content and a 0.9 -unit decline in $\mathrm{pH}$, with respect to the $\mathrm{LAB}$ inoculated silage. In support, Huisden et al [19] reported that the addition of molasses to corn silage supplied an extra source of WSC for LAB metabolism, which possibly allowed their domination in the microbial community of the silage, thereby stimulating favorable silage fermentation patterns.

Earlier findings confirmed that the combined use of the LAB inoculant and molasses improved the silage quality indices of various crops $[7,8,22]$. For example, our recent investigation [8] found that the combination of LAB and $5 \%$ molasses efficiently improved the silage quality parameters of spent mushroom substrate in both laboratory-scale and ton-bag silos. Presently, when GS was ensiled without molasses or a microbial inoculant, silage $\mathrm{pH}$ slightly declined (6.80 after $28 \mathrm{~d}$ of ensiling), which was accompanied by the high $\mathrm{NH}_{3}-\mathrm{N}$ accumulation (631 ppm). However, when GS was ensiled with $\mathrm{LAB}+\mathrm{M}$, the silage $\mathrm{pH}$ dropped to 5.3 (after $28 \mathrm{~d}$ of ensiling) and as anticipated, less $\mathrm{NH}_{3}-\mathrm{N}$ was formed (Table 2). This observation was expected, because when silage $\mathrm{pH}$ declines more quickly, excessive proteolysis is suppressed during ensiling, which contributes to less $\mathrm{NH}_{3}-\mathrm{N}$ formation
[5].

The chemical composition of GS ensiled with LAB in the absence or presence of molasses in relation to the length of ensiling, is presented in Table 3. No difference in the chemical composition was seen after $7 \mathrm{~d}$ of ensiling. However, as ensiling duration prolonged, the NDF concentration decreased in LAB+M-treated silage, which is possibly associated with the hydrolysis of cell wall fractions that are more digestible during ensiling fermentation [19].

\section{Co-ensiling of garlic stalk with citrus pulp}

This experiment evaluated the co-ensiling of GS with CP as an alternative storage technology, which has been successful in improving the silage fermentation quality of several feedstuffs [23]. For example, the recent co-ensiling of wheat straw with sugar beet waste has proved to be a successful storage method for their long-term preservation [24]. The typical silage quality parameters and chemical composition of GS and CP, ensiled alone or together (GS 70\%+CP 30\%) after 7, 14, or $28 \mathrm{~d}$ of ensiling, are reported in Tables 4 and 5, respectively. Generally, GS ensiled with CP exhibited more desirable fermentation characteristics in comparison to GS silage alone. For example, after $14 \mathrm{~d}$ of ensiling, the GS 70\%+CP 30\% silage exhibited a $56 \%$ increase in lactic acid content which represented a 0.4-unit decline in silage $\mathrm{pH}$, with respect to GS ensiled alone. The nutrient composition of GS 70\%+CP 30\% 
Table 3. Effects of microbial inoculant without or with molasses on the chemical composition of garlic stalk after 7, 14, and $28 \mathrm{~d}$ of ensiling

\begin{tabular}{|c|c|c|c|c|c|}
\hline \multirow{2}{*}{ Items } & \multicolumn{3}{|c|}{ Treatment $^{1)}$} & \multirow{2}{*}{ SE } & \multirow{2}{*}{$\mathrm{p}$-value } \\
\hline & Control & LAB & $\mathrm{LAB}+\mathrm{M}$ & & \\
\hline \multicolumn{6}{|l|}{ Ensiled for $7 \mathrm{~d}$} \\
\hline Dry matter (\%) & 64.4 & 63.3 & 63.9 & 0.73 & 0.356 \\
\hline Crude protein & 7.0 & 7.1 & 7.0 & 0.31 & 0.868 \\
\hline True protein (\% of crude protein) & 52.8 & 53.4 & 52.2 & 1.60 & 0.751 \\
\hline NPN (\% of crude protein) & 47.2 & 46.6 & 47.8 & 1.61 & 0.751 \\
\hline Crude ash & 15.5 & 15.4 & 15.2 & 0.32 & 0.666 \\
\hline NDF & 50.4 & 51.7 & 51.4 & 1.30 & 0.603 \\
\hline ADF & 49.9 & 49.7 & 48.4 & 1.21 & 0.448 \\
\hline \multicolumn{6}{|l|}{ Ensiled for $14 \mathrm{~d}$} \\
\hline Dry matter (\%) & 63.5 & 63.1 & 61.5 & 1.14 & 0.191 \\
\hline Crude protein & $6.4^{b}$ & $6.6^{b}$ & $7.3^{\mathrm{a}}$ & 0.20 & 0.012 \\
\hline True protein ( $\%$ of crude protein) & $56.2^{\mathrm{a}}$ & $52.2^{\mathrm{ab}}$ & $48.4^{b}$ & 1.71 & 0.004 \\
\hline NPN (\% of crude protein) & $43.8^{b}$ & $47.8^{\mathrm{ab}}$ & $51.6^{\mathrm{a}}$ & 1.71 & 0.004 \\
\hline Crude ash & 16.9 & 16.1 & 16.7 & 0.81 & 0.560 \\
\hline NDF & $48.8^{\mathrm{ab}}$ & $49.9^{\mathrm{a}}$ & $46.1^{b}$ & 1.33 & 0.036 \\
\hline ADF & 50.2 & 48.9 & 47.7 & 1.31 & 0.194 \\
\hline \multicolumn{6}{|l|}{ Ensiled for $28 \mathrm{~d}$} \\
\hline Dry matter (\%) & 62.8 & 61.2 & 63.1 & 0.83 & 0.067 \\
\hline Crude protein & 6.3 & 6.8 & 6.7 & 0.21 & 0.150 \\
\hline True protein ( $\%$ of crude protein) & 52.8 & 51.4 & 52.2 & 1.81 & 0.748 \\
\hline NPN (\% of crude protein) & 47.2 & 48.6 & 47.8 & 1.84 & 0.748 \\
\hline Crude ash & $16.7^{\mathrm{a}}$ & $16.1^{\mathrm{a}}$ & $15.2^{b}$ & 0.33 & 0.003 \\
\hline NDF & $49.4^{\mathrm{a}}$ & $48.4^{\mathrm{a}}$ & $46.6^{b}$ & 0.40 & $<0.001$ \\
\hline ADF & 48.0 & 46.1 & 46.0 & 0.81 & 0.052 \\
\hline
\end{tabular}

Means of five observations.

$\mathrm{SE}$, standard error; NPN, non-protein nitrogen; NDF, neutral detergent fiber; $A D F$, acid detergent fiber.

1) Control, no inoculant; LAB, $0.5 \%$ (v/w) Lactobacillus plantarum KU5; LAB+M, 0.5\% (v/w) Lactobacillus plantarum KU5+5\% molasses.

Values are based on \% of DM, unless stated.

a,b Means with different superscripts within the same row differ.

Table 4. Effects of the co-ensiling of garlic stalk with citrus pulp on the silage quality parameters after 7, 14, and $28 \mathrm{~d}$ of ensiling

\begin{tabular}{lccccc}
\hline & \multicolumn{3}{c}{ Treatment $^{1)}$} & & \\
\cline { 2 - 4 } Items & GS & CP & GS 70\% & SE & p-value \\
& $100 \%$ & $100 \%$ & + CP 30\% & & \\
\hline d 0 (before ensiling) & & & & & \\
pH & $7.5^{\mathrm{a}}$ & $3.2^{\mathrm{c}}$ & $5.7^{\mathrm{b}}$ & 0.11 & $<0.001$ \\
Lactic acid (\% of DM) & $0.16^{\mathrm{b}}$ & $2.45^{\mathrm{a}}$ & $0.19^{\mathrm{b}}$ & 0.09 & $<0.001$ \\
Ensiled for 7 d & & & & & \\
pH & $6.6^{\mathrm{a}}$ & $3.0^{\mathrm{c}}$ & $5.6^{\mathrm{b}}$ & 0.10 & $<0.001$ \\
Lactic acid (\% of DM) & $0.17^{\mathrm{b}}$ & $1.84^{\mathrm{a}}$ & $0.20^{\mathrm{b}}$ & 0.10 & $<0.001$ \\
Ensiled for 14 d & & & & & \\
pH & $6.3^{\mathrm{a}}$ & $3.1^{\mathrm{c}}$ & $5.9^{\mathrm{b}}$ & 0.11 & $<0.001$ \\
Lactic acid (\% of DM) & $0.16^{\mathrm{b}}$ & $1.02^{\mathrm{a}}$ & $0.25^{\mathrm{b}}$ & 0.10 & $<0.001$ \\
Ensiled for 28 d & & & & & \\
pH & $5.7^{\mathrm{a}}$ & $3.1^{\mathrm{b}}$ & $5.4^{\mathrm{a}}$ & 0.10 & $<0.001$ \\
Lactic acid (\% of DM) & $0.18^{\mathrm{b}}$ & $1.12^{\mathrm{a}}$ & $0.26^{\mathrm{b}}$ & 0.08 & $<0.001$ \\
\hline
\end{tabular}

Means of five observations.

$\mathrm{SE}$, standard error; DM, dry matter.

1) GS, garlic stalk; CP, citrus pulp.

${ }^{a-c}$ Means with different superscripts within the same row differ. silage was comparable to that of GS ensiled alone. However, after 14 and $28 \mathrm{~d}$ of ensiling, a greater NFC concentration was recorded for GS 70\%+CP 30\% silage, which is associated with an NDF content that diminished as ensiling time continued. For example, after $28 \mathrm{~d}$ of ensiling, NDF concentration decreased by $7.5 \%$ with respect to GS silage, which was possibly caused by the dissolution of the more digestible NDF fractions during ensiling [19]. These findings showed promise in the possibility of the successful preservation of GS when co-ensiled with $\mathrm{CP}$, leading to the follow-up experiments to determine the proper mixing level of GS and CP for efficient silage fermentation.

The pH of GS co-ensiled with incremental proportions of $\mathrm{CP}$ is illustrated in Figure 1. After $14 \mathrm{~d}$ of ensiling, the $\mathrm{pH}$ of GS 50\%+CP 50\% silage declined markedly, which is suggestive of successful silage fermentation that is known to slow down or inhibit the growth of fungi, molds, and yeasts [25]. Consistent with our findings, Migwi et al [23] reported that when $5 \%$ molasses was added to the mixture of wheat straw+ broiler litter, no effect on silage $\mathrm{pH}$ was detected. However, when the proportion of CP increased from 0 to $30 \%$ in the 
Table 5. Effects of the co-ensiling of garlic stalk with citrus pulp on the chemical composition after 7, 14, and 28 d of ensiling

\begin{tabular}{|c|c|c|c|c|c|}
\hline \multirow[b]{2}{*}{ Items } & \multicolumn{3}{|c|}{ Treatment $^{1)}$} & \multirow[b]{2}{*}{ SE } & \multirow[b]{2}{*}{$\mathrm{p}$-value } \\
\hline & GS $100 \%$ & CP $100 \%$ & $\begin{array}{l}\text { GS 70\% } \\
+ \text { CP 30\% }\end{array}$ & & \\
\hline \multicolumn{6}{|l|}{ Ensiled for $0 \mathrm{~d}$} \\
\hline Dry matter (\%) & $61.1^{b}$ & $13.7^{c}$ & $63.4^{a}$ & 0.31 & $<0.001$ \\
\hline Crude protein & $5.4^{b}$ & $9.3^{\mathrm{a}}$ & $5.5^{b}$ & 0.12 & $<0.001$ \\
\hline NDF & $52.1^{\mathrm{a}}$ & $24.0^{b}$ & $51.5^{\mathrm{a}}$ & 2.22 & $<0.001$ \\
\hline Ether extract & $1.8^{\mathrm{b}}$ & $4.2^{\mathrm{a}}$ & $2.1^{b}$ & 0.30 & $<0.001$ \\
\hline Crude ash & $13.4^{\mathrm{a}}$ & $4.1^{b}$ & $12.8^{\mathrm{a}}$ & 0.43 & $<0.001$ \\
\hline \multicolumn{6}{|l|}{ Ensiled for $7 \mathrm{~d}$} \\
\hline Dry matter (\%) & $62.0^{a}$ & $13.4^{b}$ & $63.0^{\mathrm{a}}$ & 0.64 & $<0.001$ \\
\hline Crude protein & $5.3^{b}$ & $9.4^{\mathrm{a}}$ & $5.4^{b}$ & 0.26 & $<0.001$ \\
\hline NDF & $52.5^{a}$ & $27.3^{b}$ & $52.5^{\mathrm{a}}$ & 2.61 & $<0.001$ \\
\hline Ether extract & $1.7^{b}$ & $2.5^{\mathrm{a}}$ & $1.9^{b}$ & 0.11 & $<0.001$ \\
\hline Crude ash & $14.4^{\mathrm{a}}$ & $4.1^{c}$ & $12.8^{b}$ & 0.40 & $<0.001$ \\
\hline \multicolumn{6}{|l|}{ Ensiled for $14 \mathrm{~d}$} \\
\hline Dry matter (\%) & $63.0^{b}$ & $13.7^{c}$ & $64.8^{\mathrm{a}}$ & 0.51 & $<0.001$ \\
\hline Crude protein & $5.1^{b}$ & $9.1^{\mathrm{a}}$ & $5.5^{b}$ & 0.23 & $<0.001$ \\
\hline NDF & $56.6^{\mathrm{a}}$ & $26.7^{c}$ & $43.4^{b}$ & 1.04 & $<0.001$ \\
\hline Ether extract & $1.7^{\mathrm{b}}$ & $3.4^{\mathrm{a}}$ & $2.1^{b}$ & 0.21 & $<0.001$ \\
\hline Crude ash & $12.9^{\mathrm{a}}$ & $4.0^{b}$ & $12.6^{\mathrm{a}}$ & 0.32 & $<0.001$ \\
\hline \multicolumn{6}{|l|}{ Ensiled for $28 \mathrm{~d}$} \\
\hline Dry matter (\%) & $61.5^{b}$ & $14.0^{c}$ & $62.8^{\mathrm{a}}$ & 0.34 & $<0.001$ \\
\hline Crude protein & $5.2^{b}$ & $9.2^{\mathrm{a}}$ & $5.6^{b}$ & 0.25 & $<0.001$ \\
\hline NDF & $54.1^{\mathrm{a}}$ & $24.6^{c}$ & $46.5^{b}$ & 1.30 & $<0.001$ \\
\hline Ether extract & $1.9^{b}$ & $3.9^{\mathrm{a}}$ & $2.1^{b}$ & 0.12 & $<0.001$ \\
\hline Crude ash & $13.3^{\mathrm{a}}$ & $4.0^{b}$ & $13.0^{\mathrm{a}}$ & 0.21 & $<0.001$ \\
\hline
\end{tabular}

Means of five observations.

$\mathrm{SE}$, standard error; NDF, neutral detergent fiber.

1) GS, garlic stalk 100\%; CP, citrus pulp 100\%; GS+CP, garlic stalk 70\%+citrus pulp 30\%.

Values are based on \% of DM, unless stated.

${ }^{a-c}$ Means with different superscripts within the same row differ. silage, the $\mathrm{pH}$ declined markedly [23]. Similarly, when CP was ensiled alone, lactic acid concentration was negligible (1.02\% of DM, after $14 \mathrm{~d}$ of ensiling; Figure 2). However, when $\mathrm{CP}$ was co-ensiled with GS at a 50:50 proportion, lactic acid production increased markedly (6.0\% of DM, after $14 \mathrm{~d}$ of ensiling).

The silage fermentation, sensory, and physical parameters of GS co-ensiled with incremental proportions of CP are shown in Table 6 . After 2 weeks of fermentation, despite the substantial increase in lactic acid production with increasing $\mathrm{CP}$ proportion (Figure 2), total viable colonies of $\mathrm{LAB}$ remained unaffected with increasing proportions of $\mathrm{CP}$ in the silage. This might be explained by the counting technique used, as this requires actively growing cells. It has been proposed that many LAB exist on the biomass surfaces that are viable but not culturable by using the traditional plating methods [26]. Assuming this proposition, it appears that the increased availability of metabolic water provided by the increased proportion of CP into GS biomass supported the higher metabolic activity of the microbial ecology of silage, particularly LAB [27]. In agreement, Muck [28] ensiled alfalfa at different DM levels (17\% to $73 \%$ ) and found that the greatest levels of lactic acid were produced in silages of $40 \%$ to $55 \% \mathrm{DM}$. Likewise, Mthiyane et al [29] found that when water was added to sugarcane tops silage, lactic acid production was restricted, which was explained by the multiplication and domination of heterofermentative LAB in highmoisture silage, as this generates the mixed metabolites of acetic acid, ethanol, and lactic acid. Essentially, silage making at the optimal moisture level should provide enough moisture for LAB growth and metabolism to decrease $\mathrm{pH}$ and prevent the growth of putrefactive microorganisms, while also providing enough dryness to minimize effluent pro-

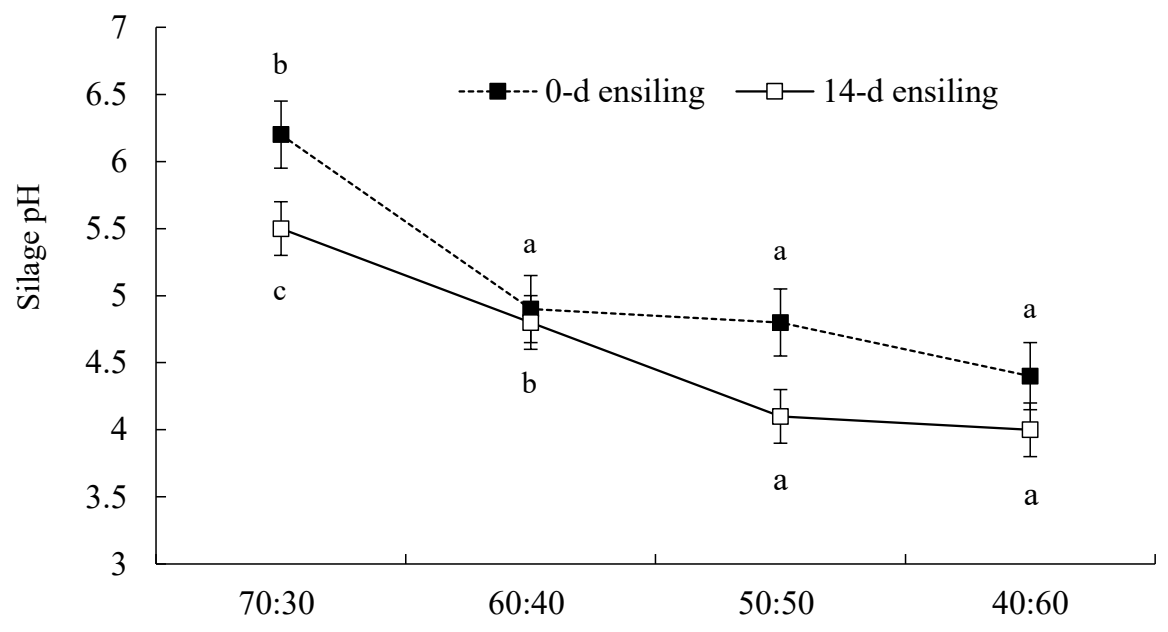

Garlic stalk:citrus pulp mixing ratio

Figure 1. Changes in silage pH of garlic stalk co-ensiled with citrus pulp at varying proportions. $\mathbf{m}, 0 \mathrm{~d}$ of ensiling; $\square$, after $14 \mathrm{~d}$ of ensiling. ${ }^{\text {acc }}$ Means with different letters within the same line differ $(p<0.05)$. Error bars at each point represent standard error. 


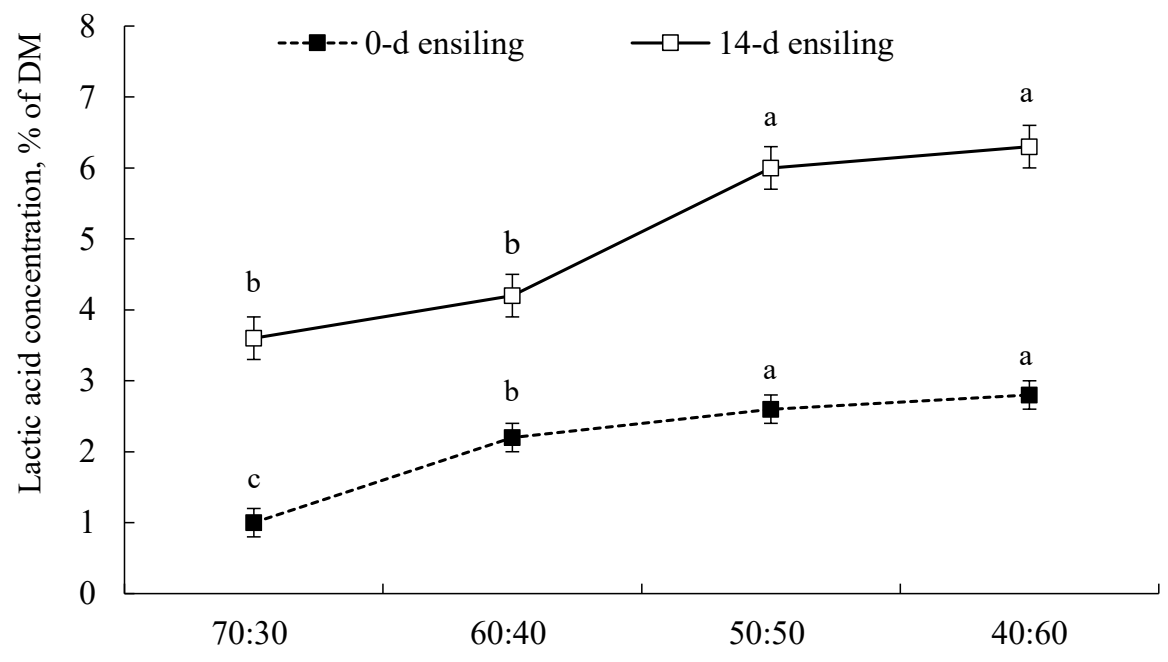

Garlic stalk:citrus pulp mixing ratio

Figure 2. Lactic acid concentration of garlic stalk co-ensiled with citrus pulp at varying proportions. $\mathbf{m}, 0 \mathrm{~d}$ of ensiling; $\square$, after $14 \mathrm{~d}$ of ensiling. ${ }^{\text {a-c }}$ Means with different letters within the same line differ $(p<0.05)$. Error bars at each point represent standard error.

duction [5,13]. Presently, it appears that the 50:50 mixing proportion provided the appropriate moisture level that favored the metabolic activity of LAB in the mixed silage of GS and CP, and thus promoted substantial lactic acid production. However, the reasons why lactic acid production increased with moisture alterations of the silage are still not clear and necessitate more studies to identify the contributory factors to this observation.

As the GS: $\mathrm{CP}$ mixing proportion decreased, $\mathrm{NH}_{3}-\mathrm{N}$ concentration lessened, which is indicative of diminished proteolysis and deamination during ensiling [5]. After $14 \mathrm{~d}$ of ensiling, $\mathrm{NH}_{3}-\mathrm{N}$ content accounted for $25.4 \%$ of the total $\mathrm{N}$ in GS $50 \%+\mathrm{CP} 50 \%$ silage, which is approximately $70 \%$ less than the silages with $30 \%$ or $40 \% \mathrm{CP}$. The fast acidification of silage

Table 6. Effects of the addition of citrus pulp to garlic stalk on the silage quality, sensory, and physical parameters after $14 \mathrm{~d}$ of ensiling

\begin{tabular}{|c|c|c|c|c|c|c|}
\hline \multirow{2}{*}{ Items } & \multicolumn{4}{|c|}{ Treatment $^{1)}$} & \multirow{2}{*}{ SE } & \multirow{2}{*}{$p$-value } \\
\hline & GS $70 \%+C P 30 \%$ & GS $60 \%+$ CP $40 \%$ & GS $50 \%+$ CP $50 \%$ & GS $40 \%+$ CP $60 \%$ & & \\
\hline \multicolumn{7}{|l|}{ d 0 (before ensiling) } \\
\hline WSC (of DM) & 1.7 & 1.8 & 1.9 & 1.7 & 0.12 & 0.233 \\
\hline $\mathrm{NH}_{3}-\mathrm{N}(\mathrm{ppm})$ & $291^{b}$ & $395^{\mathrm{a}}$ & $279^{b}$ & $248^{b}$ & 29.1 & $<0.001$ \\
\hline \multicolumn{7}{|l|}{ Ensiled for $14 \mathrm{~d}$} \\
\hline WSC ( $\%$ of DM) & 1.7 & 1.9 & 1.9 & 1.8 & 0.14 & 0.418 \\
\hline $\mathrm{NH}_{3}-\mathrm{N}(\mathrm{ppm})$ & $444^{\mathrm{ab}}$ & $533^{\mathrm{a}}$ & $325^{\mathrm{bc}}$ & $279^{c}$ & 36.7 & $<0.001$ \\
\hline Lactic acid bacteria, $\log _{10}\left(\mathrm{fu} / \mathrm{g}^{2)}\right.$ & 7.3 & 7.2 & 7.7 & 7.1 & 0.20 & 0.101 \\
\hline \multicolumn{7}{|l|}{ Sensory and physical parameters } \\
\hline Fermentation odor ${ }^{3)}$ & $3.0^{b}$ & $3.1^{\mathrm{b}}$ & $3.4^{\mathrm{a}}$ & $3.4^{\mathrm{a}}$ & 0.10 & $<0.001$ \\
\hline Putrid odor ${ }^{4)}$ & 0 & 0 & 0 & 0 & - & - \\
\hline Garlic odor ${ }^{5)}$ & $1.0^{\mathrm{a}}$ & $0.6^{b}$ & $0.4^{c}$ & $0.3^{c}$ & 0.11 & $<0.001$ \\
\hline Moldy appearance ${ }^{6)}$ & 0 & 0 & 0 & 0 & - & - \\
\hline Absorption degree $^{7)}$ & $3.6^{\mathrm{b}}$ & $4.0^{\mathrm{a}}$ & $4.2^{\mathrm{a}}$ & $3.4^{b}$ & 0.12 & $<0.001$ \\
\hline
\end{tabular}

Means of five observations.

SE, standard error; WSC, water-soluble carbohydrates; DM, dry matter.

1) $G S$, garlic stalk; CP, citrus pulp.

${ }^{2)}$ Colony-forming units per gram of fresh biomass or silage mass.

${ }^{3)}$ Based on a 5-point scale as follows: 1 = very bad, $2=$ bad, $3=$ moderate, $4=$ good, 5 = very good.

4) Based on a 2-point scale as follows: $0=$ no putrid odor, 1 = putrid odor.

5) Based on a 2-point scale as follows: 0 = no garlic odor, 1 = garlic odor.

${ }^{6)}$ Based on a 2-point scale as follows: $0=$ no moldy appearance, 1 = moldy appearance.

7) Based on a 5-point scale as follows: 1 = negligible, 5 = very much.

${ }^{a-c}$ Means with different superscripts within the same row differ. 
mass suppresses the growth of putrefying microorganisms, this probably occurred as the mixing ratio of GS:CP decreased, resulting in a lower formation of $\mathrm{NH}_{3}-\mathrm{N}$, which is associated with the improved utilization of silage- $\mathrm{N}$ and thus microbial protein synthesis in the rumen [20]. Decreasing the porosity of forage silage mass using supplementary feed sources, such as corn meal, with fine particle sizes may accelerate the silage $\mathrm{pH}$ decline, diminish inefficient plant respiration (less heat generation), and thus promote effective anaerobic fermentation [30]. This series of events is known to minimize proteolysis, which is accelerated at high silage $\mathrm{pH}$ and temperature [20]. It appears that the co-mixing of CP and GS decreased the porosity of the GS mass, which thereby promoted efficient silage fermentation that minimized $\mathrm{NH}_{3}-\mathrm{N}$ formation.

No putrid odor or moldy spots were detected in the experimental silages (Table 6), which suggests that the silages underwent a successful fermentation. However, fermentation odor increased and garlic odor decreased as the incremental levels of $\mathrm{CP}$ were incorporated into GS silage. The absorption degree was highest when $40 \%$ or $50 \%$ CP was incorporated into GS, which indicates that the effluent lost from $\mathrm{CP}$ was efficiently assimilated into GS biomass. This finding is of great importance as $\mathrm{CP}$ has a high moisture content and its ensiling alone would cause problems associated with effluent and silage nutrient losses [12], which can be minimized when co-ensiled with GS at the proper mixing ratio. Overall, this experiment found that when GS and CP were combined at a 50:50 propor- tion, the best ensiling and physical properties were achieved, as demonstrated by the domination of $\mathrm{LAB}$, low final $\mathrm{pH}$, substantial lactic acid formation, and negligible effluent loss, thus opening an avenue for the simultaneous and long-term conservation of these waste residues.

The chemical composition of GS co-ensiled with incremental proportions of $\mathrm{CP}$ is shown in Table 7. As the proportion of $\mathrm{CP}$ increased in the silage mass the $\mathrm{DM}, \mathrm{NDF}$, and ether extract contents declined, and NFC content increased as expected. After $14 \mathrm{~d}$ of ensiling, GS 50\%+CP 50\% silage resulted in a $6.9 \%$ reduction in NDF content, with respect to GS ensiled with $30 \% \mathrm{CP}$, resulting in a higher NFC concentration, which is suggestive of the improved feed-nutritional quality of the mixed silage of GS and CP for ruminant feed.

\section{CONCLUSION}

A huge amount of GS is generated during the harvesting season, an amount considerably exceeding the immediate use. This surplus is mainly composted into soil or incinerated, which is associated with serious environmental concerns. The simultaneous application of L. plantarum inoculant and molasses favorably promoted the silage fermentation quality of GS. As an alternate storage method, the effective silage fermentation was also achieved when GS was co-ensiled with $\mathrm{CP}$ at the mixing ratio of 50:50. Co-ensiling of GS with CP appears to be a simple and feasible method of preservation, which would provide the more efficient utilization of these

Table 7. Effects of the addition of incremental proportions of citrus pulp to garlic stalk on the chemical composition after $14 \mathrm{~d}$ of ensiling

\begin{tabular}{|c|c|c|c|c|c|c|}
\hline \multirow{2}{*}{ Items } & \multicolumn{4}{|c|}{ Treatment $^{1)}$} & \multirow{2}{*}{ SE } & \multirow{2}{*}{$p$-value } \\
\hline & GS $70 \%+C P 30 \%$ & GS $60 \%+$ CP $40 \%$ & GS $50 \%+$ CP $50 \%$ & GS $40 \%+$ CP $60 \%$ & & \\
\hline \multicolumn{7}{|l|}{$\mathrm{d}-0$ (before ensiling) } \\
\hline Dry matter (\%) & $63.5^{\mathrm{a}}$ & $57.4^{b}$ & $45.5^{c}$ & $44.5^{c}$ & 1.44 & $<0.001$ \\
\hline Crude protein & $7.7^{\mathrm{ab}}$ & $7.8^{\mathrm{a}}$ & $7.5^{\mathrm{ab}}$ & $7.3^{\mathrm{b}}$ & 0.10 & 0.014 \\
\hline NDF & $41.5^{b}$ & $44.7^{\mathrm{a}}$ & $37.5^{c}$ & $35.0^{c}$ & 1.01 & $<0.001$ \\
\hline Acid detergent fiber & $45.2^{b}$ & $49.4^{\mathrm{a}}$ & $42.3^{c}$ & $43.2^{b c}$ & 1.04 & $<0.001$ \\
\hline Ether extract & $1.4^{\mathrm{a}}$ & $1.1^{\mathrm{b}}$ & $1.1^{\mathrm{b}}$ & $1.2^{b}$ & 0.12 & 0.001 \\
\hline Crude ash & $12.6^{\mathrm{a}}$ & $10.2^{c}$ & $11.1^{b}$ & $11.7^{\mathrm{ab}}$ & 0.31 & $<0.001$ \\
\hline NFC & $36.8^{b}$ & $36.2^{b}$ & $42.8^{\mathrm{a}}$ & $44.8^{\mathrm{a}}$ & 1.10 & $<0.001$ \\
\hline \multicolumn{7}{|l|}{ Ensiled for $14 \mathrm{~d}$} \\
\hline Dry matter (\%) & $62.9^{a}$ & $56.3^{b}$ & $48.3^{c}$ & $42.2^{d}$ & 2.14 & $<0.001$ \\
\hline Crude protein & $7.8^{b}$ & $9.3^{\mathrm{a}}$ & $8.0^{b}$ & $7.9^{b}$ & 0.15 & $<0.001$ \\
\hline NDF & $44.3^{\mathrm{a}}$ & $45.3^{\mathrm{a}}$ & $37.4^{b}$ & $32.9^{c}$ & 0.50 & $<0.001$ \\
\hline Acid detergent fiber & $44.7^{\mathrm{ab}}$ & $46.9^{\mathrm{a}}$ & $43.1^{b}$ & $38.8^{c}$ & 1.03 & $<0.001$ \\
\hline Ether extract & $1.7^{\mathrm{b}}$ & $2.0^{\mathrm{a}}$ & $2.1^{\mathrm{a}}$ & $2.1^{\mathrm{a}}$ & 0.11 & 0.004 \\
\hline Crude ash & 12.4 & 12.6 & 12.5 & 11.8 & 0.34 & 0.167 \\
\hline NFC & $33.8^{c}$ & $30.8^{d}$ & $40.0^{b}$ & $45.3^{\mathrm{a}}$ & 0.63 & $<0.001$ \\
\hline
\end{tabular}

Means of five observations.

SE, standard error; NDF, neutral detergent fiber; NFC, non-fibrous carbohydrates; DM, dry matter.

${ }^{1)} \mathrm{GS}$, garlic stalk; $\mathrm{CP}$, citrus pulp.

Values are based on \% of DM, unless stated.

${ }^{a-d}$ Means with different superscripts within the same row differ. 
waste resources over longer periods, especially in places where they are generated in large quantities.

\section{CONFLICT OF INTEREST}

We certify that there is no conflict of interest with any financial organization regarding the material discussed in the manuscript.

\section{ACKNOWLEDGMENTS}

This study was also supported by Konkuk University in 2018 .

\section{REFERENCES}

1. Faostat (Food and Agriculture Organization of the United Nations). FAO Statistical Databases [Internet] [cited 2018 Dec 6]. Available from: http://faostat.fao.org/

2. Kamruzzaman M, Liang X, Sekiguchi N, Sano H. Effect of feeding garlic leaf on microbial nitrogen supply, kinetics of plasma phenylalanine, tyrosine and protein synthesis in sheep. Anim Sci J 2014;85:542-8. https://doi.org/10.1111/asj.12190

3. Lee YH, Kim YI, Oh YK, Ahmadi F, Kwak WS. Yield survey and nutritional evaluation of garlic stalk for ruminant feed. J Anim Sci Technol 2017;59:22. https://doi.org/10.1186/s40781017-0147-3

4. Kallel F, Ellouz-Chaabouni S. Perspective of garlic processing wastes as low-cost substrates for production of high-added value products: a review. Environ Prog Sustain Energy 2017; 36:1765-77. https://doi.org/10.1002/ep.12649

5. McDonald P, Henderson AR, Heron SJE. The biochemistry of silage. Marlow, Bucks, UK: Chalcombe Publications; 1991.

6. Weinberg ZG, Muck RE. New trends and opportunities in the development and use of inoculants for silage. FEMS Microbiol Rev 1996;19:53-68. https://doi.org/10.1016/0168-6445(96)000 25-3

7. Ni K, Wang F, Zhu B, et al. Effects of lactic acid bacteria and molasses additives on the microbial community and fermentation quality of soybean silage. Bioresour Technol 2017;238: 706-15. https://doi.org/10.1016/j.biortech.2017.04.055

8. Kim JS, Lee YH, Kim YI, et al. Effect of microbial inoculant or molasses on fermentative quality and aerobic stability of sawdust-based spent mushroom substrate. Bioresour Technol 2016;216:188-95. https://doi.org/10.1016/j.biortech.2016. 05.056

9. Kim KS, Park SM, Park KJ, Kim SS, Hyun JW, Hwang RJ. Status of the citrus industry in Republic of Korea. In IX International Symposium on Temperate Zone Fruits in the Tropics and Subtropics 1059; 2014. pp. 51-8. https://doi.org/10.17660/ ActaHortic.2014.1059.4

10. Satari B, Karimi K. Citrus processing wastes: environmental impacts, recent advances, and future perspectives in total valorization. Resour Conserv Recycl 2018;129:153-67. https:// doi.org/10.1016/j.resconrec.2017.10.032

11.Scerra V, Caparra P, Foti F, Lanza M, Priolo A. Citrus pulp and wheat straw silage as an ingredient in lamb diets: Effects on growth and carcass and meat quality. Small Rumin Res 2001;40:51-6. https://doi.org/10.1016/S0921-4488(00)002 $08-\mathrm{X}$

12. Bampidis VA, Robinson PH. Citrus by-products as ruminant feeds: a review. Anim Feed Sci Technol 2006;128:175-217. https://doi.org/10.1016/j.anifeedsci.2005.12.002

13. Gebrehanna MM, Gordon RJ, Madani A, VanderZaag AC, Wood JD. Silage effluent management: a review. J Environ Manag 2014;143:113-22. https://doi.org/10.1016/j.jenvman. 2014.04.012

14.AOAC International. Official methods of analysis. 19th ed. Arlington, VA, USA: AOAC Int.; 2012.

15.Licitra G, Hernandez TM, Van Soest PJ. Standardization of procedures for nitrogen fractionation of ruminant feeds. Anim Feed Sci Technol 1996;57:347-58. https://doi.org/10.1016/ 0377-8401(95)00837-3

16. Dubois M, Gilles KA, Hamilton JK, Rebers P, Smith F. Colorimetric method for determination of sugars and related substances. Anal Chem 1956;28:350-6. https://doi.org/10.1021/ ac60111a017

17. Barker SB, Summerson WH. The colorimetric determination of lactic acid in biological material. J Biol Chem 1941;138: 535-54.

18. Chaney AL, Marbach EP. Modified reagents for determination of urea and ammonia. Clin Chem 1962;8:130-2. https://doi. org/10.1093/clinchem/8.2.130

19. Huisden CM, Adesogan AT, Kim SC, Ososanya T. Effect of applying molasses or inoculants containing homofermentative or heterofermentative bacteria at two rates on the fermentation and aerobic stability of corn silage. J Dairy Sci 2009; 92:690-7. https://doi.org/10.3168/jds.2008-1546

20. Muck RE. Factors influencing silage quality and their implications for management. J Dairy Sci 1988;71:2992-3002. https:// doi.org/10.3168/jds.S0022-0302(88)79897-5

21. Ávila CLS, Carvalho BF, Pinto JC, Duarte WF, Schwan RF. The use of Lactobacillus species as starter cultures for enhancing the quality of sugar cane silage. J Dairy Sci 2014;97:940-51. https://doi.org/10.3168/jds.2013-6987

22. Zhao J, Dong Z, Li J, et al. Effects of lactic acid bacteria and molasses on fermentation dynamics, structural and nonstructural carbohydrate composition and in vitro ruminal fermentation of rice straw silage. Asian-Australas J Anim Sci 2019; 32:783-91. https://doi.org/10.5713/ajas.18.0543

23. Migwi PK, Gallagher JR, Van Barneveld RJ. Effect of molasses on the fermentation quality of wheat straw and poultry litter ensiled with citrus pulp. Anim Prod Sci 2000;40:825-9. https:// doi.org/10.1071/EA99011

24. Hillion ML, Moscoviz R, Trably E, et al. Co-ensiling as a new 
technique for long-term storage of agro-industrial waste with low sugar content prior to anaerobic digestion. Waste Manag 2018;71:147-55. https://doi.org/10.1016/j.wasman.2017.10. 024

25. Muck R. Recent advances in silage microbiology. Agric Food Sci 2013;22:3-15. https://doi.org/10.23986/afsci.6718

26. McAllister TA, Dunière L, Drouin P, et al. Silage review: Using molecular approaches to define the microbial ecology of silage. J Dairy Sci 2018;101:4060-74. https://doi.org/10.3168/jds.201713704

27. Whiter AG, Kung Jr L. The effect of a dry or liquid application of Lactobacillus plantarum MTD1 on the fermentation of alfalfa silage. J Dairy Sci 2001;84:2195-202. https://doi.org/10. 3168/jds.S0022-0302(01)74666-8

28. Muck RE. Dry matter level effects on alfalfa silage quality II.
Fermentation products and starch hydrolysis. Trans ASAE 1990;33:373-81. https://doi.org/10.13031/2013.31340

29. Mthiyane DMN, Nsahlai IV, Bonsi MLK. The nutritional composition, fermentation characteristics, in sacco degradation and fungal pathogen dynamics of sugarcane tops ensiled with broiler litter with or without water. Anim Feed Sci Technol 2001;94:171-85. https://doi.org/10.1016/S0377-8401(01)00 311-X

30. Sibanda S, Jingura M, Topps JH. The effect of level of inclusion of the legume Desmodium uncinatum and the use of molasses or ground maize as additives on the chemical composition of grass- and maize-legume silages. Anim Feed Sci Technol 1997;68:295-305. https://doi.org/10.1016/S0377-8401(97)00 $049-7$ 